ANADOLU, J. of AARI

ISSN: 1300-0225 (Print)

E-ISSN: 2667-6087 (Online)

2019, 29 (2): 103-113

DOI: $10.18615 /$ anadolu.660263

\title{
Narda Çiçek Tomurcuğu Alım Dönemi, Karanlık Rejimi ve Bitki Büyüme Düzenleyicilerinin Anter Kültürü̈ Üzerine Etkileri
}

\author{
Müge ŞAHIN ${ }^{1 *}$ (D) Selay DOĞAN ${ }^{2}$ \\ ${ }^{1,2}$ Ege Tarımsal Araştırma Enstitüsü Müdürlü̆̆̈̈, Menemen-İzmir/TURKEY \\ ${ }^{1}$ https://orcid.org/0000-0002-5570-9143 $\quad{ }^{2}$ https://orcid.org/0000-0003-0589-3963 \\ * Corresponding author (Sorumlu yazar): mugesahin67@hotmail.com \\ Received (Geliş tarihi): 13.05.2019Ａccepted (Kabul tarihi): 17.08.2019
}

ÖZ: Nar (Punica granatum L.), Türkiye'de yetiştiriciliği ve ihracatı ile ön plana çıkan bir meyve türüdür. Anter kültürü tekniği ile ıslah çalışmalarının desteklenmesi, özellikle meyve türlerinde zor olan haploidizasyonun sağlanması açısından önemlidir. Narda in vitro androgenesis yöntemi ile haploid bitki elde edilmesi konusunda yayına rastlanılmamıştır. Bu çalışmada, İzmir 1513 nar çeşidinde farklı tomurcuk alım dönemleri, karanlık rejimleri ve bitki büyüme düzenleyicilerinin anter kültürüne olan etkilerinin belirlenmesi amaçlanmıştır. Materyal olarak 1. dönem (25 Mayls-tam çiçeklenme) ve 2. dönemdeki (10 Haziran-çiçeklenme sonu) A tipi çiçek tomurcukları kullanılmıştır. Kültüre alınan anterlere 4 ve 6 hafta karanlık rejimi uygulanmıştır. Kültür ortamı olarak MS besi ortamına eklenen BAP, 2,4-D ve NAA'nın farklı konsantrasyon ve kombinasyonlarından oluşan 5 farkl ortam denenmiştir. Denemelerin sonucunda uygulamaların hem ana etkisi hem de interaksiyonu istatistiksel açıdan önemli bulunmuştur. En yüksek kallus gelişimi (\% 23,33), 2. dönemde alınan çiçek tomurcuklarından elde edilen anterlerin, 4,0 mg/l NAA + 0,4 mg/l BAP ortaminda kültüre alınmasl ve 6 hafta süreyle karanlı uygulamasından elde edilmiştir. Aynı uygulamada sürgün oluşumu da gerçekleşmiştir. Diğer taraftan, oksin içeren ortamlarda kök oluşumları gözlemlenmiştir. Pembe, yeşil, sarı ve beyaz renklerde kalluslar oluşmuştur. Pembe ve yeşil renkli kalluslar kompakt ve sert, sarı ve beyaz renkli kalluslar ise kırllgan ve yumuşak yapılı olarak tespit edilmiștir. Kallus renkleri, bitki büyüme düzenleyicileri konsantrasyonları ve kombinasyonları uygulamalara göre farklılık göstermemiş, oluşan kallusların tamamında farklı embriyojenik dönemler gözlenmiştir.

Anahtar Kelimeler: Nar, Punica granatum L., anter kültürü, haploidi, karanlık rejimi, tomurcuk alım dönemi, bitki büyüme düzenleyicileri.

\section{Effects of Taken Time of Flower Buds, Dark Regime and Plant Growth Regulators on Anther Culture of Pomegranate}

\begin{abstract}
Pomegranate (Punica granatum L.) is a fruit species that comes to the forefront with its high amount of cultivation and exportation in Turkey. Supporting the breeding studies with anther culture technique, which is one of the biotechnological methods, is important especially in terms of ensuring the haploidization that is difficult in fruit species. According to the literature research, there has been no publication of haploid plant production on pomegranate by using in vitro androgenesis method in the world. The aim of this study is to determine the effects of taken time of flowers buds, dark regime and plant growth regulators on anther culture of Izmir 1513 pomegranate variety. In this context, type A flower buds in $1^{\text {st }}$ period (25 May-full flowering) and $2^{\text {nd }}$ period (10 June-end of flowering) were used. Four and 6 weeks dark regime was implemented on cultivated anthers. MS medium were used with 5 different concentrations and combinations of BAP, 2,4-D and NAA. At the end of the experiments, both the main effect and the interaction of the applications were statistically significant. The highest callus growth (23.33\%) was obtained on $4.0 \mathrm{mg} / \mathrm{l} \mathrm{NAA}+0.4 \mathrm{mg} / \mathrm{l}$ BAP culture medium with the taken time of flower buds on $2^{\text {nd }}$ period and dark application for 6 weeks. In this application, which has the highest callus development, shoot formation has also occurred. Root formations were observed in all auxin-containing mediums. Calluses were colored in 4 different colors; pink, green, yellow and white. However, the pink and green calluses are compact and rigid, while the yellow and white colored calluses are fragile and soft structure. The callus colors did not differ according to the plant growth regulator concentrations and applications, in addition different embryogenic periods were observed in all calluses.
\end{abstract}

Keywords: Pomegranate, Punica granatum L., anther culture, haploidy, dark regime, taken time of flowers buds, plant growth regulators. 


\section{GíRiș}

Bitki 1slahı, bitkinin genetik yapısının istenilen özellikler doğrultusunda iyileştirilmesini içeren, insanoğlunun oluşturduğu evrimsel bir süreçtir. Temeli, iyi olan bitkilerin seçildiği seleksiyon 1slahına dayanmaktadır. Doğada spontan varyasyonun değerlendirilmesi ile başlayan sslah çalışmaları suni melezleme ve mutasyon gibi yöntemlerle oluşturulan varyasyonlardan, istenilen özellikteki bitkilerin seçilmesi ile devam etmiştir. Günümüzde ise, moleküler yöntemlerden yararlanılması 1slah çalışmalarına biyoteknolojik bir boyut kazandırmıştır.

Son y1llarda biyoteknolojik yöntemlerden biri olan ve hibrit tohum ıslahında önemli yer tutan haploidi tekniği, meyve türleri de dâhil olmak üzere birçok bitki türünde yaygın olarak kullanılmaktadır. Bugüne kadar 200 bitki türünde farklı yöntemlerle haploid bitkiler elde edilmiş ve bu bitkiler katlanarak double haploid bitkiler meydana getirilmiștir (Forster ve ark., 2007). Bilindiği gibi, çok yıllık ve yüksek heterozigotiye sahip olan meyve türlerinin klasik yöntemler ile 1slahı (seleksiyon, melezleme, mutasyon vb.) uzun soluklu çalışmaları kapsamaktadır. Bu türlerde, yüksek oranda heterozigosite, uzun gençlik kısırlığ periyodu ve kendine uyuşmazlık nedeniyle, konvansiyonel metotlarla haploidizasyon sağlanması oldukça zordur (Germanà, 2005). Anter kültürü yöntemi sayesinde tam homozigoti çok kısa sürelerde elde edilmekte (Jain ve ark., 1997) ve bu sayede 1slah süresi kısaltılabilmektedir.

Anter kültüründe birçok faktör etkili olup, her tür için bu faktörlerin belirlenmesi gerektiğine dikkat çekilmektedir (Radojevic ve Koovor, 1986). Bu faktörler genotip, ağaç yaşı, tomurcuk alım zamanı, çiçek tozu gelişim aşaması, düşük\&yüksek sıcaklık, 1şık\&karanlık uygulamaları, besi ortamı, aktif karbon ve bitki ekstraktları gibi besi ortamına eklenen bileşenler, sakkaroz kaynakları, bitki büyüme düzenleyicileri ve konsantrasyonları, agar kaynakları ve kallus yaşı olarak sıralanmaktadır (Stiles ve ark., 1980; Hidano, 1982; Chen, 1985; Hassawai ve Liong, 1990; Hoefer ve Hanke, 1990; Pescitelli ve ark., 1990; Jaramillo ve Summers,
1991; Arrillaga ve ark., 1995; Mićić ve ark., 1996; Ochatt ve Zhang, 1996; Kadota ve ark., 2002; Assani ve ark., 2003; Kadota ve Niimi, 2004; Peixe ve ark., 2004; Germanà, 2005; Perera ve ark., 2009; Smýkalová ve ark., 2009; Nguyen ve ark., 2012).

Meyve ağaçlarında haploid bitki eldesi ile ilgili yapılan çalışmalar, sert ve yumuşak çekirdekli meyve türlerinde in vitro androgenesis yöntemi üzerine yoğunlaşarak 1970'li yıllarda başlamıştır (Zhang ve ark., 1989).

Yumuşak çekirdekli meyve türlerinde, farklı agar, soğuk, 1șık, karanlık ve sitokinin uygulamalarının anter kültürüne olan etkilerinin incelendiği çalışmada, kallus oluşumunu bazı çeşitlerde soğuk, bazı çeşitlerde ise 1 şı uygulamasının arttırdığı belirlenmiştir. Karanlık uygulaması ise sadece bir çeşitte kallus oluşumunu arttırmıştır. Farklı sitokinin kaynaklarının kullanımı ise istatistiksel olarak önemsiz çıkmıştır (Kadota ve ark., 2002). Elma çeşitlerinde, farklı dozlarda indol-3-asetik asit (IAA), $\alpha$-naftalen asetik asit (NAA) ve kinetin ilave edilen MS (Murashige\&Skoog) ortamlarında kallus ve embriyo oluşumu incelenmiş, çeşitler arasında kallus oluşumunun önemli oranda varyasyon gösterdiği tespit edilmiştir. Hormon içermeyen MS ortamı ve $0,1 \mathrm{mg} / 1$ kinetin içeren ortamda kallus oluşumunun arttığ 1 ifade edilmiştir. Ortama IAA ve NAA'nin kallus oluşumuna olumlu etkide bulunurken, NAA'nin anter duvar dokularından kallus oluşumunu arttırdığı belirlenmiştir. Shinko armut çeşidinde ise 1şık, aktif kömür ve soğuk ön uygulamalarının anter kültürüne olan etkileri incelenmiştir (Hidano, 1982). Hormonsuz MS ortamında kültüre alınan 24.625 armut anterinden 8.888 'inde kallus oluştuğu, bunlardan da yalnızca 6 tanesinin embriyojenik kallus olduğu tespit edilmiştir. Yapılan flow sitometri analizleri sonucunda, rejenerasyon ortamina aktarilan bu kalluslardan elde edilen iki bitkinin triploid olduğu belirlenmiştir (Kadota ve Nimii, 2004). Alkmene ve Clivia elma çeşitleri ile 2 islah hattında, anter kültürünün 3 ve 6 ay aralığında direk organogenesis aracılığıyla embriyo oluşturduğu gözlenmiştir (Hoefer ve Hanke, 1990). 
Sert çekirdekli meyve türlerinde; $0,5,14$ ve 25 gün $+4{ }^{\circ} \mathrm{C}$ soğuk uygulamas1, NN, Gamborgs' B5 ve çift bazlı MS ortamlarına farklı konsantrasyonlarda glisin, sistein, indol bütirik asit (IBA), BAP, $\mathrm{GA}_{3}$ ilavesinin anter kültürüne olan etkileri incelenmiştir. Soğuk uygulaması ile kallus oluşumu artmış, beyaz-kırılgan ve yeşil-kompakt olmak üzere 2 farklı tipte kallus gelişimi gözlenmiştir. İncelenen genotiplerde soğuk ve bitki büyüme düzenleyici uygulamasının haploid kallus ve bitkicik oluşumu üzerine etkisi görülmemiş ancak bazı anterlerde iç anter dokularından kallus oluşumları gözlemlenmiştir. Sitogenik olarak incelenen kallusların diploid olduğu, haploid kallus oluşmadığı belirlenmiştir (Mićić ve ark., 1996). Harcot kayısı çeşidinde, MS ve NN (Nitsch\&Nitsch) ortamları ile farklı dozlarda NAA, thidiazuron (TDZ), IAA, zeatin ve $\mathrm{GA}_{3}$ (gibberellik asit) hormonları kullanılmıştır. En iyi androjenik gelişim 4,52 $\mu \mathrm{M} \quad 2,4 \mathrm{D}+4,52 \mu \mathrm{M}$ zeatin $+2,85 \mu \mathrm{M}$ IAA $+40 \mathrm{~g} / 1$ sakkaroz ilave edilen NN ortamından elde edilmiştir. Androjenik gelişimin tomurcuk büyüklüğü ve mikrosporların fenolojik evresi ile korelasyon gösterdiği, en uygun anterlerin ise tetrad aşamasında mikrosporları içeren anterler olduğu belirlenmiştir (Peixe ve ark., 2004). Şeftalide, spor gelişiminin erken dönemlerinde kültüre alınan anterlerde, 2,0 ppm NAA, 0,45 ppm BA, 10 ppm amonyum nitrat ve $\% 1$ sakkaroz içeren ortamlarda en yüksek kallus oluşumu elde edilmiştir. Bu kalluslarda haploid, diploid, poliploid ve anöploid hücreler gözlenmiştir (Stiles ve ark., 1980). Kirazda ise BA (benzil adenin), NAA, 2,4-D (2-4 diklorofenoksi asetik asit) hormonları ile MS ve NN ortamları kullanılmış ve anterlere yapılan soğuk uygulamalarından en iyi sonuçlar elde edilmiştir (Hoefer ve Hanke, 1990).

Sert ve yumuşak çekirdekli meyve türlerinin yanı sıra ülkelere göre ekonomik önemi yüksek olan türlerde de yapılan çalışmalar bulunmaktadır. Üvezde (Sorbus domestica L.) kallus oluşumu için büyüme düzenleyicilerin ortamda bulunması gerektiği ve en iyi sonuçların oksin-BA kombinasyonlarından (Arrillaga ve ark., 1995), nim ağacında (Azadirachta indica) ise androjenik haploidlerin anterlerin erken-geç uninucleat aşamasına kadar olan dönemde yapılan denemeler sonucunda indirekt organogenesis yoluyla elde edildiği belirtilmektedir (Chaturvedi ve ark., 2003).

Muzda, MS makro ve mikro elementleri, Morel vitaminleri ve $500 \mathrm{mg} / 1$ casein hidrolizat $(\mathrm{CH}), 73$ $\mathrm{mM}$ sakkaroz, 4,4 $\mu \mathrm{M}$ BAP (benzil amino pürin) ve 2,3 $\mu \mathrm{M}$ IAA içeren tek bir ortamda anterler kültüre alınmıştır. Rejenerasyon aşamasında ise yukarıdaki temel besi ortamı ve vitaminlere ilave olarak $88 \mathrm{mM}$ sakkaroz, 2,2 $\mu \mathrm{M}$ BAP, $2,3 \mu \mathrm{M}$ IAA kullanılmıştır. Anterlerin \% 8'inin androjenik embriyo oluşturduğu ve elde edilen 147 bitkicikten 18'inin haploid yapıda olduğu tespit edilmiştir (Assani ve ark., 2003). Çilekte, tek çekirdekli dönemdeki mikrosporları içeren anterlerin, 0,4 $\mathrm{mg} / \mathrm{l} \mathrm{BA}+0,1 \mathrm{mg} / \mathrm{l} \mathrm{IAA}+2,0 \mathrm{mg} / \mathrm{l}$ 2,4-D doz ve kombinasyonlarını içeren Dumas De Vaulx besi ortamında en yüksek oranda $(\% 70)$ kallus oluşturduğu belirlenmiştir (Nguyen ve ark., 2012).

Punica granatum ile yapılan anter kültürü çalışmasında, tek çekirdekli dönemden iki çekirdekli döneme kadar farklı aşamalardaki sporlara sahip nar anterleri 3 farklı besi ortamı (MS, Miller, NN) ve farklı dozlarda NAA ve BAP içeren besi ortamlarında, $28{ }^{\circ} \mathrm{C}$ 'de karanlık koşullarda bir ay süreyle kültüre alınmışlardır. Kültüre alınan anterlerin \% 20'si canlı olarak tespit edilmiş, MS ve Miller ortamlarında 5,0 $\mu \mathrm{M}$ BAP ve NAA düzeylerinde yeşil-beyaz renkli kallus oluşumları gözlemlenmiştir (Moriguchi ve ark., 1987). Ganesh ve Muskat nar çeşitlerinde yapılan anter kültürü çalışmaları sonucunda, $0,5 \mathrm{mg} / 1$ Kinetin $+0,5 \mathrm{mg} / \mathrm{l} \mathrm{IAA}+0,2 \mathrm{mg} / \mathrm{l} \mathrm{BAP}$ içeren NN ortamında yeşil ve kompakt yapılı kalluslar ile embriyoid benzeri yapılar görülmüştür. NN ortamına $0,5-1,0 \mathrm{mg} / \mathrm{l}$ IAA eklenmesi ile kök oluşumu, besi ortamı içerisine eklenen $0,1-4,3 \mathrm{mg} / 1$ BAP ile de yaprak oluşumu gerçekleştiği belirtilmiş̧ir (Mascarenhas ve ark., 1988).

Yukarıda bahsedildiği gibi, dünya genelinde narda anter kültürü ile ilgili yapılan iki çalıșma bulunmaktadır. Moriguchi ve ark. (1987), elde ettikleri bitkiciğin, anter duvarlarında bulunan somatik hücrelerden geliştiğini ve bunun diploid 
yapıda olduğunu tespit etmişlerdir. Diğer taraftan, Mascarenhas ve ark. (1988) ise anterlerden kök ve yaprak geliştiği ancak bitkicik elde edilemediğini bildirmektedir. Bu bağlamda, söz konusu türde, in vitro androgenesis yöntemi ile haploid bitki eldesi konusunda yayına rastlanılmamıştır.

Narda kültür çeşitlerinin çiçekleri er-dişidir, A ve B tipi çiçek olmak üzere 2 tip çiçek bulunmaktadır (Wetzstein ve ark., 2011). A tipi çiçekler morfolojik er-dişi, fizyolojik olarak ise dişi organ dumura uğradığı için, erkek yapıdadır. A tipi çiçekler açıldıktan bir süre sonra dökülür ve tek işlevleri B tipi çiçeklerin döllenmesinde görev almaktır. B tipi çiçekler, hem morfolojik hem de fizyolojik yönden er-dişi olup, döllenme sonucunda meyveyi oluşturmaktadırlar (Onur, 1988). A tipi çiçek sayısının B tipi çiçeklerden fazla olması ve A tipi çiçeklerin çiçek tozu canlılıklarının B tipi çiçeklerinkinden daha yüksek olmas1 nedeniyle (Shulman ve ark., 1984; ElKassas ve ark., 1998; Gozlekci ve Kaynak, 2000) döllenmede rol oynayan çiçek tozlarının genel olarak A tipi çiçeklerden geldiği belirtilmektedir (Aksoy ve Dalkılıc, 2019). Ayrica 6 farklı nar çeşidinde yapılan çalışmada en yüksek çiçek tozu canlılık oranı \%73,20 ile İzmir 1513 çeşidinin A tipi çiçeğinde belirlenmiştir (Küçük, 2003).

Nar çiçek tomurcuklarında yukarıda anlatılan farklılıklardan dolayı, İzmir 1513 nar çeşidinin A tipi çiçek tomurcukları kullanılmış ve bitki büyüme düzenleyicileri, farklı tomurcuk alım dönemleri ile karanlık rejimlerinin, anter kültürü ile kallus, embriyo ve haploid bitkicik oluşumu üzerine etkilerinin belirlenmesi amaçlanmıştır.

\section{MATERYAL VE YÖNTEM}

\section{Bitkisel Materyal ve Sterilizasyon Aşaması}

Çalışmada, Ege Tarımsal Araştırma Enstitüsü tescilli nar çeşitlerinden biri olan İzmir 1513 nar çeşidine ait 1-1,5 $\mathrm{cm}$ boyutundaki A tipi çiçek tomurcukları kullanılmıştır. Tomurcuklar tam çiçeklenme (1. Dönem: 25 Mayıs 2013) ve çiçeklenme sonu (2. Dönem: 10 Haziran 2013) olmak üzere iki farklı dönemde, enstitü arazisinden toplanarak Bitki Doku Kültürü Merkezi’ne getirilmiştir.

Tomurcuklar, akan su altında yıkandıktan sonra 30 dakika boyunca \%2'lik sistemik fungusit (Aliette ${ }^{\circledR}$ ) çözeltisinde karıştırılmıştır. Laminar akımlı kabine alınan tomurcuklar \%70'lik etil alkolde 1 dakika bekletilmiş ve ardından steril saf su ile durulanmıştır. Ardından içerisinde birkaç damla Tween 20 bulunan \%20'lik $\mathrm{NaOCl}$ solüsyonunda 15 dakika karıştırılmış ve 3 defa saf su ile durulanarak sterilizasyon işlemi tamamlanan çiçek tomurcukları kurutma kâğıtları üzerinde kurutulmuştur.

\section{Anterlerin Kültüre Alınması ve Uygulamalar}

Çalışmada, \%3 sakkaroz ve \%0,7 agar ile desteklenen MS (Murashige ve Skoog, 1962) besi ortamı ve bitki büyüme düzenleyicilerinden, BAP'ın 2,4 D ve NAA ile hazırlanmış farklı kombinasyonlarını içeren 5 farklı besi ortamı $(0,4$ $\mathrm{mg} / \mathrm{l} \mathrm{BAP} ; 2,0 \mathrm{mg} / \mathrm{l}$ 2,4-D + 0,4 mg/l BAP; 2,0 $\mathrm{mg} / \mathrm{l} \mathrm{NAA}+0,4 \mathrm{mg} / \mathrm{l}$ BAP; 4,0 mg/l 2,4-D + 0,4 $\mathrm{mg} / \mathrm{l}$ BAP; $4,0 \mathrm{mg} / \mathrm{l} \mathrm{NAA}+0,4 \mathrm{mg} / \mathrm{l}$ BAP) kullanılmıştır. Kontrol ortamına ise bitki büyüme düzenleyici (BBD) ilavesi yapılmamıştır. Tüm ortamların pH'1 5,7 olarak ayarlanmıştır. $121{ }^{\circ} \mathrm{C}$ sicaklıkta 20 dakika süreyle otoklavlanan besi ortamları laminar akımlı kabin içerisinde steril petrilere dökülmüştür. Sterilizasyonu tamamlanan çiçek tomurcuklarından pens ve bistüri yardımıyla anterler dikkatli bir şekilde çıkarılmış ve petri kapları (10x100 mm) içerisinde bulunan besi ortamlarında kültüre alınmıştır.

Her iki dönemde kültüre alınan anterlere 4 ve 6 hafta karanlık rejimi uygulanmıştır. Karanlık uygulamalarının ardından petriler, $25 \pm 2^{\circ} \mathrm{C}^{\prime}$ de 16 saat aydınlık/8 saat karanlık periyodu ve 3000 lüx 1şık altında iklim odasında kültüre alınmıştır. Anterlerden oluşan kalluslar aynı BBD konsantrasyonu içeren ortamlarda 6 hafta aralıklarla 2 defa alt kültüre alınmıştır.

\section{İstatistik Analizler}

Deneme 3 tekerrürlü, her tekerrürde 1 petri ve her petride 20 adet anter olacak şekilde Tesadüf 
Parselleri Deneme Desenine göre kurulmuştur. Anterlerin farklı dönem ve uygulamalarda kültüre alınmasına ait deneme planı Çizelge 1'de görülmektedir. Deneme sonucunda elde edilen veriler ile her tekerrür için anter gelişim oranlarına (\%) logaritmik transformasyon uygulanmış ve bu verilere varyans analizi, JMP istatistik paket programı kullanılarak uygulanmıştır. Ortalamalar arasındaki farklar LSD testi ile karşılaştırılmıştır (Steel ve Torrie, 1980; Yurtsever, 1984).

\section{BULGULAR ve TARTISYMA}

In vitro çalışmalarda sterilizasyon yöntemlerinin başarısı tüm çalışmanın başarısını etkilemektedir. $\mathrm{Bu}$ nedenle başlangıç aşamasında eksplanta uygulanan sterilizasyon yöntemlerinin dikkatli bir şekilde yapılması gerekmektedir. Bu çalışmada, Mayıs ve Haziran dönemlerinde araziden toplanan çiçek tomurcuklarına uygulanan sterilizasyon işlemleri sonrasında herhangi bir kontaminasyon ile karşılaşılmamıştır.

Bitkilerin savunma, korunma, hayatta kalma, nesillerini sürdürme gibi çevresel koşullara uyum faaliyetleri esnasında üretilmekte olan sekonder metabolitlerden biri de, özellikle meyve ve sebze türlerinde salgılanan fenolik bileşiklerdir. $\mathrm{Bu}$ bileşikler, bitki doku kültürü çalışmalarında bitkinin gelişimini engelleyici etki göstermektedir (Erkoyuncu ve Yorganc1lar, 2015). Fougat ve ark. (1997), Punica granatum'a ait kotiledon ve yaprak parçalarını kullanarak yapmış oldukları in vitro mikroçoğaltım çalışmasında, başlangıçta fenolik bileşik salgılarından kaynaklanan bir dizi problemle karşılaştıklarını belirtmişlerdir. Çalışmamızda da fenolik bileşenlerin yüksek olması nedeniyle anterlerin önemli bir kısmında kararma meydana gelmiştir. Kararma oluşan anterlerin gelişimleri engellenmiş ve canlılığını kaybettiği için de bu anterlerde kallus oluşumu gerçekleşmemiştir.

\section{BBD Konsantrasyonlarının Kallus Oluşumuna Etkisi}

Anter kültürü çalışmalarında çiçek tomurcuklarının alınma zamanının yanında, bitki genotipi ve kullanılan bitki büyüme düzenleyicilerin kombinasyon ve konsantrasyonlarının da bitki eldesi için oldukça önemli olduğu belirtilmektedir (Hoefer ve Hanke, 1990; Germanà ve ark., 2011; Nguyen ve ark., 2012). In vitro çalışmalarda, bitki büyüme düzenleyicilerden oksin ve sitokinin kombinasyonları sıklıkla kullanılmakla birlikte, doğrudan bitkicik rejenerasyonu için en çok kullanılan sitokinin olan BAP konsantrasyonlarının iyi değerlendirilmesi gerekmektedir. Diğer yandan indirekt organogenesis yöntemi ile kallus eldesinden haploid bitkilerin elde edilmesi gibi özel amaçlar doğrultusundaki biyoteknolojik çalışmalar uygulanacak ise yüksek oranlarda belirlenen oksin grubu bitki büyüme düzenleyiciler devreye girmektedir.

Çizelge 1. Deneme planı.

Table 1. Trial plan.

\begin{tabular}{|c|c|c|c|c|c|}
\hline \multirow{3}{*}{$\begin{array}{l}\text { Bitki büyüme düzenleyicileri } \\
\text { Plant growth regulators }\end{array}$} & \multicolumn{5}{|c|}{$\begin{array}{l}\text { Uygulamalar } \\
\text { Treatments }\end{array}$} \\
\hline & \multicolumn{2}{|c|}{$\begin{array}{l}\text { 1. dönem (25 Mayis 2013) } \\
1^{\text {st }} \text { period (25 May 2013) }\end{array}$} & \multicolumn{3}{|c|}{$\begin{array}{l}\text { 2. dönem (10 Haziran 2013) } \\
2^{\text {nd }} \text { period (10 June 2013) }\end{array}$} \\
\hline & $\begin{array}{l}4 \text { hafta karanlık } \\
4 \text { weeks dark }\end{array}$ & $\begin{array}{l}6 \text { hafta karanlik } \\
6 \text { weeks dark }\end{array}$ & $\begin{array}{l}4 \text { hafta karanlık } \\
4 \text { weeks dark }\end{array}$ & $\begin{array}{l}6 \text { hafta karanlık } \\
6 \text { weeks dark }\end{array}$ & $\begin{array}{c}\text { Toplam } \\
\text { Total }\end{array}$ \\
\hline $0,4 \mathrm{mg} / \mathrm{l} \mathrm{BAP}$ & 3 petri*20 anter & 3 petri* 20 anter & 3 petri* 20 anter & 3 petri*20 anter & 240 \\
\hline $2,0 \mathrm{mg} / \mathrm{l} 2,4-\mathrm{D}+0,4 \mathrm{mg} / \mathrm{l} \mathrm{BAP}$ & 3 petri $* 20$ anter & 3 petri $* 20$ anter & 3 petri* 20 anter & 3 petri $* 20$ anter & 240 \\
\hline $2,0 \mathrm{mg} / \mathrm{l} \mathrm{NAA}+0,4 \mathrm{mg} / \mathrm{BAP}$ & 3 petri $* 20$ anter & 3 petri $* 20$ anter & 3 petri $* 20$ anter & 3 petri $* 20$ anter & 240 \\
\hline $4,0 \mathrm{mg} / 1$ 2,4-D + 0,4 mg/l BAP & 3 petri $* 20$ anter & 3 petri $* 20$ anter & 3 petri $* 20$ anter & 3 petri $* 20$ anter & 240 \\
\hline $4,0 \mathrm{mg} / \mathrm{l} \mathrm{NAA}+0,4 \mathrm{mg} / \mathrm{l} \mathrm{BAP}$ & 3 petri $* 20$ anter & 3 petri $* 20$ anter & 3 petri $* 20$ anter & 3 petri $* 20$ anter & 240 \\
\hline Kontrol (Control) & 3 petri $* 20$ anter & 3 petri $* 20$ anter & 3 petri $* 20$ anter & 3 petri $* 20$ anter & 240 \\
\hline $\begin{array}{l}\text { Toplam kültüre alınan anter say } \\
\text { Total number of anthers taken i }\end{array}$ & & & 1440 & & \\
\hline
\end{tabular}


Yapılan çalışmada kullanılan bitki büyüme düzenleyicilerden, sitokinin ve oksin-sitokinin kombinasyonlarının tamamında kallus oluşumları gözlemlenmiş ve kallus oluşumuna olan ana etkisi istatistiksel olarak $(\mathrm{P} \leq 0,01)$ önemli bulunmuştur (Çizelge 2).

Çizelge 2. Bitki büyüme düzenleyicilerinin kallus oluşumuna etkileri (\%).

Table 2. Effects of plant growth regulators on callus formation (\%).

\begin{tabular}{|c|c|}
\hline Bitki büyüme düzenleyicileri & Kallus olușumu (\%) \\
\hline Plant growth regulators & Callus formation (\%) \\
\hline 0,4 mg/l BAP & $1,67 \quad \mathrm{~d}^{*}$ \\
\hline $2,0 \mathrm{mg} / \mathrm{l} 2,4-\mathrm{D}+0,4 \mathrm{mg} / \mathrm{l} \mathrm{BAP}$ & 7,50 \\
\hline $2,0 \mathrm{mg} / \mathrm{l} \mathrm{NAA}+0,4 \mathrm{mg} / \mathrm{l} \mathrm{BAP}$ & 4,58 \\
\hline $4,0 \mathrm{mg} / \mathrm{l} 2,4-\mathrm{D}+0,4 \mathrm{mg} / \mathrm{l} \mathrm{BAP}$ & 5,00 \\
\hline $4,0 \mathrm{mg} / \mathrm{l} \mathrm{NAA}+0,4 \mathrm{mg} / \mathrm{l} \mathrm{BAP}$ & 13,33 \\
\hline Kontrol & 0,00 \\
\hline
\end{tabular}

CV (\%): 26,99

$\operatorname{LSD}(0,01): 1,26^{* *}$

${ }^{*}$ Farklı harflerle gösterilen ortalamalar arasındaki fark 0,01 seviyesinde önemlidir ("Means followed by different letters are significantly different at 0.01 level of significance).

${ }^{*}$ Log transforme verilere ait CV ve LSD değerler verilmiștir. Daha anlașılır olması açısından tabloda \% değerler yer almıștır $\left(^{* *} \mathrm{CV}\right.$ and LSD values of log transformed data are given. For clarity, only \% values are included in the table).

Çalışmada kullanılan 5 farklı besi ortamında, kallus oluşturma oranları, aynı oranda kullanılan oksinlerden 2,4-D'ye nazaran NAA'da daha yüksek oranda gözlenmiştir. Narda yürütülen bu çalışmada, en yüksek kallus oluşumu $4,0 \mathrm{mg} / 1$ NAA ve $0,4 \mathrm{mg} / \mathrm{l}$ BAP içeren MS ortamlarından elde edilmiştir $(\% 13,33)$. Bununla birlikte, azalan NAA ile BAP kombinasyonlarının bulunduğu besi ortamlarında kültüre alınan anter eksplantlarında kallus oluşumunun azaldığı gözlenmiştir. 2,0 mg/l NAA ve $0,4 \mathrm{mg} / 1$ BAP içeren MS ortamında kallus eldesi \% 4,58 oranında belirlenmiştir (Çizelge 2). Kallus kültürü için, en uygun besi ortamının MS ve en iyi bitki büyüme düzenleyici kombinasyonlarının da NAA+BAP ve NAA+Kinetin'in farkl konsantrasyonları olduğu belirtilmektedir (Naik ve Chand, 2011). Moriguchi ve ark. (1987), nar anterlerini BA ve NAA içeren besi ortamlarında kültüre aldıktan 30 gün sonra anter duvarlarında kallus oluştuğunu belirtmişlerdir. Hoefer ve Hanke (1990), kallus oluşumunun elmada \% 2-48, kirazda \% 0,1-7 aralığında değişim gösterdiğini ve en yüksek oranların $1 \mathrm{mg} / \mathrm{l} \mathrm{NAA}+1 \mathrm{mg} / \mathrm{l} \mathrm{BAP}$ içeren ortamlardan elde edildiğini, ayn 1 zamanda $0,5 \mathrm{mg} / 1$
2,4-D + 0,5 mg/l BAP içeren ortamların ise bu bakımdan ikinci en iyi ortam olduğunu belirlemiştir. Nim ağacinda, $1 \mu \mathrm{M}$ 2,4-D $+1 \mu \mathrm{M}$ $\mathrm{NAA}+5 \mu \mathrm{M}$ ilave edilmiş MS ortamlarında kallus oluşumu en iyi oranda gerçekleşirken, en iyi kallus gelişiminin ise $1 \mu \mathrm{M} 2,4-\mathrm{D}+10 \mu \mathrm{M}$ kinetin içeren ortamda olduğu belirtilmiştir (Chaturvedi ve ark., 2003).

Çalışmada, 2,0 mg/1 2,4-D + 0,4 mg/l BAP besi ortamı $\% 7,5$ oranıyla, en iyi kallus gelişiminin görüldüğü ikinci ortam olarak belirlenmiştir. Bununla birlikte 4,0 mg/l 2,4-D + 0,4 mg/l BAP ortamında kallus oranı düşük (\%5) olup, bu iki ortam arasındaki fark istatistik açıdan önemli bulunmamıştır. 2,4-D konsantrasyonunun artmasıyla birlikte kallus oluşumu bakımından belirli bir artışın ortaya çıkmamasının, kullanılan dozun yüksek olduğundan kaynaklandığı düşünülmektedir. Elmada, tüm genotipler ve tüm sitokinin konsantrasyonları için 2,4-D'nin $0,4 \mathrm{mg} / 1$ gibi düşük dozdaki varlığının kallus oluşumunu önemli ölçüde arttırdığı belirtilmiştir (Hoefer ve Hanke, 1990). Sadece 0,4 mg/l BAP içeren besin ortamında ise kallus oluşumu $(\% 1,67)$ düşük oranda olup, bu ortama ek olarak kontrol grubu eksplantlarında sadece anterlerde şişmeler meydana gelmiştir.

BBD içermeyen kontrol grubunda ise kallus oluşmamıştır. Arrillaga ve ark. (1995), kallus oluşumu için büyüme düzenleyicilerin ortamda bulunması gerektiğine, oksin ve sitokinin kombinasyonlarında en yüksek kallus oluşumunun meydana gelebileceğine dikkat çekmiştir. Cresthaven ve Vesna şeftali çeşitlerinde 2,4-D + Zeatin, IAA + Zeatin ile NAA + Zeatin kombinasyonlarında kültüre alınan anterlerde kallus oluşum oranının artığını tespit edilmiştir (Todorovic ve ark., 1990). Bu bulguların aksine, elmada yapılan bir çalışmada hormonsuz MS ortamı ve buna ilave edilen $0,1 \mathrm{mg} / 1$ kinetin içeren ortamlarda kültüre alınan explantlarda meydana gelen kallus oluşumunun, kullanılan diğer ortamlara göre artış gösterdiği belirtilmiştir (Hidano, 1982).

\section{Tomurcuk Alım Dönemi ve Karanlık Uygulamalarının Kallus Oluşumuna Etkisi}

Uygulamaların kallus oluşumuna etkisi istatistiksel olarak önemli $(\mathrm{P} \leq 0,01)$ bulunmuştur (Çizelge 3$)$. 
Buna göre, kültüre alınan ve 4-6 hafta süre ile karanlık şartlara maruz birakılan anterlerden, tomurcukların her iki alım döneminde de, 6 hafta karanlık uygulamasında kallus oluşumu bakımından daha etkili sonuçlar elde edilmiștir. Bu uygulamada kallus oluşum oranı sırasıyla $\% 4,44$ ve $\% 10,56$ olarak tespit edilmiştir. Birinci dönemde (25 Mayıs) alınan ve 4 hafta in vitro karanlık uygulamasina maruz kalan anterlerde ise kallus oluşumu en düşük oranda $(\% 1,39)$ görülmüştür.

Çizelge 3. Uygulamaların kallus oluşumuna (\%) etkileri.

Table 3. Effects of treatments on callus formation (\%).

\begin{tabular}{|c|c|}
\hline $\begin{array}{l}\text { Uygulamalar } \\
\text { Treatments }\end{array}$ & $\begin{array}{l}\text { Kallus oluşumu (\%) } \\
\text { Callus formation (\%) }\end{array}$ \\
\hline 1. dönem +4 hafta karanlık & $1,39 \quad \mathrm{c}^{*}$ \\
\hline 1. dönem +6 hafta karanlık & 4,44 \\
\hline 2. dönem +4 hafta karanlık & 5,00 \\
\hline 2. dönem +6 hafta karanlık & 10,56 \\
\hline
\end{tabular}

CV (\%): 26,99*

$\operatorname{LSD}(0,01): 1,02^{* *}$

"Farkl1 harflerle gösterilen ortalamalar arasındaki fark 0,01 seviyesinde önemlidir ("Means followed by different letters are significantly different at 0.01 level of significance).

${ }^{* *}$ Log. transformasyon uygulanan verilere ait CV ve LSD değerler verilmiştir $\left({ }^{* *} \mathrm{CV}\right.$ and LSD values of log transformed data are given).

Karanlık uygulama süresinin artmasına paralel olarak kallus oluşumu ve kallus çapının arttığı bildirilmektedir (Hoefer ve Hanke, 1990; Jaramillo ve Summers, 1991; Kadota ve Niimi, 2004; (Peixe ve ark., 2004). Buna karş1lık, armut ve elma çeşitlerinin anter kültüründe 1 şık uygulamasının kallus oluşumunu arttırdığı, ancak bir çeşitte karanlık uygulamasının etkin olduğu belirlenmiştir
(Kadota ve ark., 2002). Soğuk ve karanlık ön uygulamas1 yapılan anterlerin, aktif kömür eklenmemiş ortamlarda kültüre alınması ile kallus oluşumunun yüksek oranda $(\% 85,8)$ görüldüğü belirtilmiştir (Kadota ve Nimii, 2004).

Tomurcuk alım dönemleri göz önünde bulundurulduğunda 2. dönemde alınan çiçek tomurcuğuna ait anterlerin, 1. döneme göre daha iyi kallus ve sürgün oluşturma potansiyelinin olduğu gözlenmiştir.

\section{Uygulama $X$ BBD İnteraksiyonunun Kallus Olușumuna Etkisi}

Uygulama $X$ bitki büyüme düzenleyici interaksiyonunun kallus oluşumuna etkisi istatistiksel olarak $(\mathrm{P} \leq 0,01)$ önemli bulunmuştur (Çizelge 4). En iyi kallus oluşumu \%23,33 oranı ile 2. dönemde alınan ve 6 hafta karanlık uygulamas1 yapilan anterlerin, 4,0 mg/1 NAA + 0,4 mg/1 BAP içeren MS ortamında kültüre alınmasıyla elde edilmiştir. Bunu \%20,00 oranı ile 2. dönemde alınan ve 6 hafta karanlık uygulaması yapılan anterlerin, 2,0 mg/l 2,4-D + 0,4 mg/l BAP içeren ortamlarda kültüre alınmasıyla meydana gelen kalluslar takip etmiştir. Kontrol ortamlarının yanı sıra, 2. dönemde alınan ve 4 hafta karanlık uygulamas1 yapılan anterler, $0,4 \mathrm{mg} / 1$ BAP içeren ortamlarda ve 1 . dönemde alınıp 4 hafta karanlık uygulamas1 yapilan anterlerin, $2,0 \mathrm{mg} / 12,4-\mathrm{D}+0,4$ $\mathrm{mg} / \mathrm{l}$ BAP ve 4,0 mg/l 2,4-D + 0,4 mg/l BAP içeren ortamlardaki kültürlerinde kallus gelişimi gözlenmemiştir.

Çizelge 4. Uygulama x bitki büyüme düzenleyici interaksiyonunun kallus oluşumuna (\%) etkileri.

Table 4. Effects of treatments x plant growth regulators interaction on callus formation (\%).

\begin{tabular}{|c|c|c|c|c|c|c|}
\hline \multirow[b]{2}{*}{$\begin{array}{l}\text { Uygulamalar } \\
\text { Treatments }\end{array}$} & \multicolumn{6}{|c|}{$\begin{array}{l}\text { Bitki büyüme düzenleyicileri } \\
\text { Plant growth regulators }\end{array}$} \\
\hline & $\begin{array}{l}0,4 \mathrm{mg} / \mathrm{l} \\
\text { BAP }\end{array}$ & $\begin{array}{c}2,0 \mathrm{mg} / \mathrm{l} \\
2,4-\mathrm{D}+0,4 \\
\mathrm{mg} / \mathrm{l} \mathrm{BAP}\end{array}$ & $\begin{array}{c}2,0 \mathrm{mg} / \mathrm{l} \mathrm{NAA} \\
+0,4 \mathrm{mg} / \mathrm{l} \\
\text { BAP }\end{array}$ & $\begin{array}{c}4,0 \mathrm{mg} / 1 \mathrm{2}, 4-\mathrm{D} \\
+0,4 \mathrm{mg} / 1 \\
\text { BAP }\end{array}$ & $\begin{array}{c}4,0 \mathrm{mg} / \mathrm{l} \\
\mathrm{NAA}+0,4 \\
\mathrm{mg} / \mathrm{l} \mathrm{BAP}\end{array}$ & Kontrol \\
\hline 1. dönem, 4 hafta karanlık & 3,33 ef* & $0,00 \quad \mathrm{f}$ & 3,33 ef & $0,00 \quad \mathrm{f}$ & 1,67 ef & 0 \\
\hline 1. dönem, 6 hafta karanlık & 1,67 ef & 5,00 & 1,67 ef & 6,67 & 11,67 & 0 \\
\hline 2. dönem, 4 hafta karanlık & 0,00 & 5,00 & 1,67 ef & 6,67 & 16,67 & 0 \\
\hline 2. dönem, 6 hafta karanlık & 1,67 & $20,00^{a b}$ & $11,67 \quad \mathrm{~cd}$ & 6,67 & $23,33 \quad a$ & 0 \\
\hline $\begin{array}{l}\text { CV }(\%): 26,99^{* *} \\
\operatorname{LSD}(0,01): 2,53^{* *}\end{array}$ & & & & & & \\
\hline
\end{tabular}


Farklı uygulama, çeşit ve ortam interaksiyonlarının anter kültürüne olan etkilerinin incelendiği çalışmalar bulunmaktadır (Arrillaga ve ark., 1995; Hoekstra ve ark., 1996; Mićić ve ark., 1996; Kadota ve Niimi, 2004; Germanà ve ark., 2011; Nguyen ve ark., 2012). Genel olarak meyve türlerinde; ön uygulamasız tek bir başlangıç ortamı ve/veya buna ilave tek bir regenerasyon ortam (Assani ve ark., 2003; Germanà ve ark., 2011), ön uygulamasız farklı hormon dozları (Peixe ve ark., 2004) ile ön uygulama ve hormonsuz MS başlangıç ortamıyla (Kadota ve Nimii, 2004) yapılan çalışmalar bulunmaktadır. Ancak tomurcuk alım dönemi ve karanlık rejimlerinin, bitki büyüme düzenleyicileri ile olan interaksiyonunun değerlendirildiği benzer bir çalışmaya rastlanılmamıştır.

\section{Kallus Morfolojisi ve Bitkicik Oluşumu}

Nar bitkisine ait olan anter eksplantları besi ortamlarında kültüre alındıktan 2 hafta sonra anterlerde şişmeler, 8 hafta sonra ise kallus oluşumları meydana gelmiştir. Elma ve kirazda anterler kültüre alındıktan 4-6 hafta (Hoefer ve Hanke. 1990), muzda 16 hafta sonra kallus oluşumunun başladığı belirtilmiştir (Assani ve ark., 2003). Kalluslar pembe, yeşil, sarı ve beyaz renkli olmak üzere 4 farklı renkte gelişim göstermiştir. Pembe ve yeşil kalluslar kompakt ve sert yapıda, sar1 ve beyaz renkli kalluslar ise kırılgan ve yumuşak yapıda gözlemlenmiştir (Şekil 1a). Ancak kallus renkleri, bitki büyüme düzenleyici konsantrasyonları ve uygulamalara göre farklılık göstermemiştir. Farklı meyve türlerinde yapılan anter kültürü çalışmalarında beyaz-kırılgan, yeşilkompakt, sarımsı beyaz ve sarı sert yapıda kallus oluşumları görüldüğü belirtilmiştir (Hoefer ve Hanke, 1990; Mićić ve ark., 1996; Germanà,
2005). Bununla birlikte, 4 muz genotipinde yapilan in vitro çalışmada, eksplantlarda meydana gelen kallusların kırılgan ya da kompakt yapılı olması ile genotipler arasinda herhangi bir korelasyon bulunmamıştır (Assani ve ark., 2003). Beş kayısı çeşidinde ise gelişim göstermeyen ve şişme meydana gelen anterler bakımından çeşitler arasındaki farklılık istatistiksel olarak önemli bulunmuştur (Germanà ve ark., 2011).

Kalluslarda farklı embriyojenik dönemler görülmüştür (Şekil 1a). Benzer şekilde Ganesh ve Muskat nar çeşitlerine ait anterlerden elde edilen, yeşil ve kompakt yapılı kallusların da embriyo benzeri yapılar içerdiği bildirilmektedir (Mascarenhas ve ark., 1988). Armutta yapılan çalışmada embriyojenik kallus oluşumu \%0,02 oranında meydana gelmiştir (Kadota ve Nimii, 2004).

Oksin içeren ortamlarda kök oluşumları gözlenirken (Şekil 1b), 2. dönemde alınan ve 6 hafta karanlık uygulanan anterlerin, 4,0 mg/l NAA $+0,4 \mathrm{mg} / \mathrm{l}$ BAP ilave edilmiş MS besi ortamında kültüre alınması sonucunda, indirek organogenesis yoluyla 1 adet sürgün elde edilmiştir (Şekil 1c). Zayıf gelişim gösteren, yaprakları küçük ve dar yapıda olan bu sürgünün morfolojik olarak haploid olabileceği düşünülmekte olup, alt kültüre alındıktan sonra gelişim göstermeyen ve canlılığını yitiren bu sürgünde kromozom sayısını belirlemek amaciyla kromozom sayımı, flow sitometri analizi, stoma incelenmesi gibi işlemler yapılamamıştır. Benzer şekilde, armut ve elmada yapılan anter kültürü çalışmasında 6 ay sonunda armut ve elmada anterden elde edilen bitkiciklerden, sadece bir çeşit dışında tekrardan kallusa dönüş meydana gelmediği ve tamamen bitkilerin öldüğü bildirilmektedir (Kadota ve ark., 2002). 

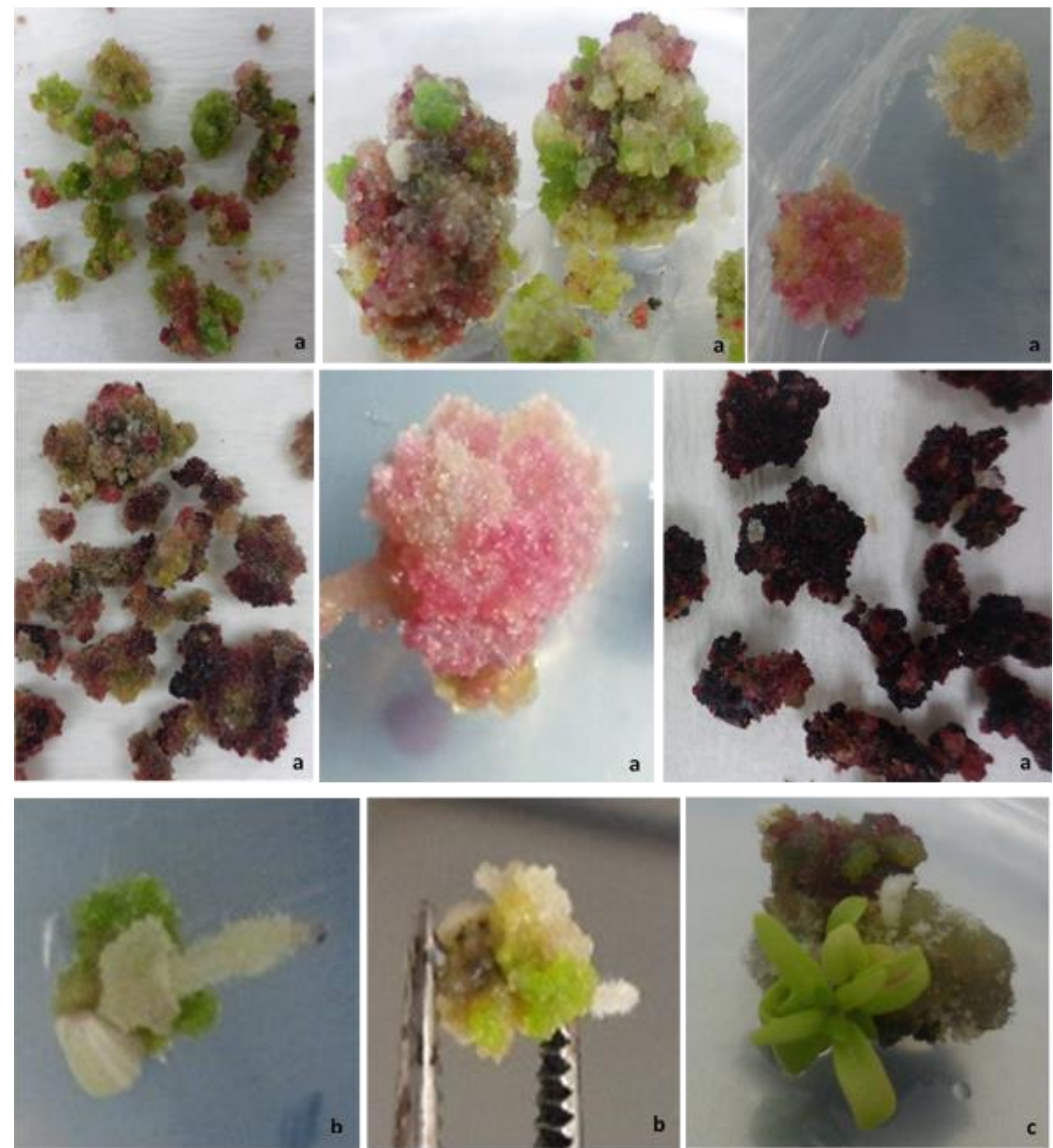

Şekil 1. Kallus renkleri ve embriyo benzeri yapılar (a), kök oluşumları (b) ve nar sürgünü (c).

Figure 1. Callus colors and embryo-like structures (a), root formation (b) and pomegranate shoot (c).

\section{SONUC}

$\mathrm{Bu}$ çalışmada, karanlık rejimi, bitki büyüme düzenleyicileri ve farklı tomurcuk alım dönemlerinin, narda anter kültürü yoluyla haploid bitki eldesi üzerine olan etkileri araştırılmıştır. En iyi kallus oranı ve sürgün oluşumu, çiçeklenme döneminin sonuna doğru alınan ve 6 hafta karanlık uygulanan anterlerin, 4,0 mg/l NAA $+0,4 \mathrm{mg} / \mathrm{l} \mathrm{BAP}$ ilave edilmiş MS besi ortamında kültüre alınmasından elde edilmiştir. Zayıf gelişim gösteren, yaprakları küçük ve dar yapıda olan sürgünün morfolojik olarak haploid olduğu düşünülmekte olup, gelişim aşamasında kaybedildiği için kesin tanıya yönelik analizler yapılamamıştır.

Doku kültürü çalışmalarında olduğu gibi anter kültüründe de, narda bulunan fenolik maddelerden dolayı kültüre alınan eksplantlarda ve besi ortamlarında kararmalar meydana gelmiştir. Fenolik bileşiklerin sebep olduğu kararmaları engellemek amaciyla yapılacak uygulamaların (ortama aktif karbon vb. maddelerin eklenmesi) başarıyı arttırabileceği düşünülmektedir. Narda androgenesis ile haploid bitki eldesine yönelik olarak yapılacak olan çalışmalarda; döllenmede rol 
oynayan ve çiçek tozu canlılık oranı yüksek olan A tipi çiçek tomurcuklarının kullanılması ve bu tomurcukların çiçeklenme döneminin sonlarına doğru alınması, karanlık rejiminin uzun tutulması ve in vitro çalışmalarda kullanılacak olan besi ortamlarında dengeli bir oksin-sitokinin oranının kullanılması önerilmektedir. Tomurcuk alım dönemi ve karanlık rejimlerinin, bitki büyüme düzenleyicileri ile olan interaksiyonunun değerlendirildiği çalışma olmadığından, yapılacak

\section{LITERATÜR LISTESI}

Aksoy, D., and Z. Dalk1lıc. 2019. Determination of Blooming, Pollen and Fruit Set Characteristics in Punica granatum. Notulae Botanicae Horti Agrobotanici ClujNapoca 47 (4). Doi: 10.15835/nbha47411216.

Arrillaga, I., V. Lerma, P. Pérez-Bermúdez, and J. Segura 1995. Callus and Somatic Embryogenesis from cultured anthers of service tree (Sorbus domestica L.). Hortscience 30 (5): 1078-1079.

Assani, A., F. Bakry, F. Kerbellec, R. Haicour, G. Wenzel, and B. Foroughi-Wehr. 2003. Production of haploids from anther culture of banana [Musa balbisiana (BB)]. Plant Cell Reports 21 (6): 511-516.

Chaturvedi, R., M. K. Razdan, and S. S. Bhojwani. 2003. Production of haploids of neem (Azadirachta indica A. Juss.) by anther culture. Plant Cell Rep. 21 (6): 531-7.

Chen, Z. 1985. A study on induction of plants from Citrus pollen. Fruit Varieties Journal (USA) 39 (2): 44-50.

El-Kassas, S. E., A. M. El-Sese, A. M. El-Salhy, and A. A. Abdalla. 1998. Bearing habits in some pomegranate cultivars. Assiut J. Agric. Sci. 29 (3): 147-162.

Erkoyuncu, T. M. ve M. Yorgancılar. 2015. Bitki doku kültürü yöntemleri ile sekonder metabolitlerin üretimi, Selçuk Tarım Bilimleri Dergisi 2 (1): 66-76.

Forster, B. P., E. Heberle-Bors, K. J. Kasha, and A. Touraev. 2007. The resurgence of haploids in higher plants. Trends in Plant Science 12 (8): 368-375.

Fougat, R. S., S. B. Pandya, T. Ahmad, and P. R. Godhani. 1997. In Vitro studies in pomegranate (Punica granatum L.) Journal-of Applied-Horticulture-Navsari $3(1-2): 23-29$.

Germanà, M. A. 2005. Protocol of somatic embryogenesis from Citrus spp. anther culture. pp. 191-207. In: S. M. Jain, and P. K. Gupta (Eds.). Protocol for Somatic Embryogenesis in Woody Plants. Springer, Dordrecht. olan çalışmalarda, çalışmamızda interaksiyonu istatistiksel olarak önemli çıkan uygulamaların da göz önünde bulundurulması önem taşıyacaktır.

\section{TEŞEKKÜR}

Bu çalışma, Ege Tarımsal Araştırma Enstitüsü’nde ön çalışma olarak gerçekleştirilmiştir. Bu konudaki destekleri için Ege Tarımsal Araştırma Enstitüsü Müdürlüğü’ne, değerli fikirleri ve yardımları için sayın Dr. Erol KÜÇÜK’e teşekkür ederiz.

Germanà, M. A., B. Chiancone, D. Padoan, I. Bárány, M. C. Risueno, and P. S. Testillano. 2011. First stages of microspore reprogramming to embryogenesis through anther culture in Prunus armeniaca L. Environmental and Experimental Botany 71 (2): 152-157.

Gozlekci, S., and L. Kaynak. 2000. Investigations on pollen production and quality in some standard pomegranate (Punica granatum L.) cultivars. CIHEAM Options Méditerranéennes: Série A. Séminaires Méditerranéens n. 42, p. 71-77.

Hassawai, D. S., J. Qi, and G. H. Liang. 1990. Effects of Growth Regulatorand Genotype of Production of Wheat and Triticale Polyhaploids from Anther Culture. Plant Breeding 104 (1): 4045

Hidano, Y. 1982. Callus and embryoid induction by anther culture of apple. Bull. Fac. Educ. Hirosaki Univ. 48: $69-74$

Hoekstra, S., S. Hoekstra, I. R. Hoekstra, R. A. Hoekstra, and E. Hoekstra. 1996. The interaction of 2,4-d application and mannitol pretreatment in anther and microspore culture of Hordeum vulgare L. cv. Igri. Journal of Plant Physiology 148 (6): 696-700.

Hoefer, M., and V. Hanke. 1990. Induction of androgenesis in vitro in apple and sweet cherry. Acta Horticulturae 280: 333-336. Doi.10.17660/ActaHortic.1990.280.56.

Jain, S. M., S. K. Sopory, and R. E. Veilleux. 1997. In Vitro Haploid Production in Higher Plants, Vol. 5, Kluwer Academic Publisher, Dordrecht, The Netherlands, London.

Jaramillo, J., and W. L. Summers. 1991. Dark-light treatments influence induction of tomato anther callus. Hortscience 26 (7): 915-916.

Kadota, M., and Y. Niimi. 2004. Production of triploid plants of Japanese pear (Pyrus pyrifolia Nakai) by anther culture. Euphytica 138 (2): 141-147.

Kadota, M., D. Han, and Y. Niimi. 2002. Plant regeneration from anther-derived embryos of apple and pear. HortScience 37 (6): 962-965. 
Küçük, E. 2003. Bazı nar (Punica granatum L.) çeşitlerinin kendine verimlilik durumlarının saptanması. Yüksek Lisans Tezi (basılmamış). Ege Üniv. F.B.E. Bahçe Bitkileri ABD, Bornova/İzmir, 38s.

Mascarenhas, A. F., S. Nair, R. S. Iyer, and P. K. Gupta. 1988 Genetic improvement of fruit crops through tissue culture. pp 41. In: Genetic manipulation in crops Proceedings of the international symposium on genetic manipulation in crops, the third international symposium on haploidy; the first international symposium on somatic cell genetics in crops. Cassell Tycooly.

Mićić, N., G. Durić, M. Dublić, and G. Dacić G. 1996. Haploid induction from anther culture of stone fruits. Acta Agriculturae Serbica 1 (2): 21-30.

Moriguchi, T., M. Omura, N. Matsula, and J. Kozaki. 1987. In vitro adventitious shoot formation from anthers of pomegranate. HortScience 22 (5): 947-948.

Murashige, T. and F. A. Skoog. 1962. Revised medium for rapid growth and bioassays with tobacco tissue cultures. Physiol. Plant. 15 (3): 473-497.

Naik, S. K. and P. K. Chand. 2011. Tissue culture-mediated biotechnological intervention in pomegranate: a review. Plant Cell Reports 30 (5): 707-721. Doi: 10.1007/s00299-010-0969-7.

Nguyen, T. X., Song, Y., Park, S. M., 2012. Haploid plant production through anther culture in day-neutral strawberry (Fragaria $x$ Ananassa Duch) Cv. Albion. J. ISSAAS 18 (1): 173-184.

Ochatt, S. J., and Y. X. Zhang. 1996. In vitro haploidization of fruit trees. pp.193-210. In: S. M. Jain, S. K. Sopory, and R. E. Veilleux (Eds.) In Vitro Haploid Production in Higher Plants. Current Plant Science and Biotechnology in Agriculture, vol 25. Springer, Dordrecht. https://doi.org/10.1007/978-94-017-1858-5

Onur, C. 1988. Nar. Derim Özel Say1 5 (4): 147-191.

Perera, P. I. P., D. M. D. Yakandawala, V. Hoccher, J. L. Verdeil, and L. K. Weerakoon. 2009. Effect of growth regulators on microspore embryogenesis in coconut anther. Plant Cell, Tissue and Organ Culture 96 (2): 171-180.
Pescitelli, S. M., C. D. Johnson, and J. F. Petolino. 1990. Isolated microspore culture of maize: effect of isolation technique, reduced temperature, and sucrose level. Plant Cell Reports 8 (10): 628-631.

Peixe, A., J. Barroso, A. Potes, and M. S. Pais. 2004. Induction of haploid morphogenic calluses from in vitro cultured anthers of Prunus armeniaca cv.'Harcot'. Plant Cell, Tissue And Organ Culture 77 (1): $35-41$.

Radojevic, L. and A. Koovor. 1986. Induction of haploids, pp. 65-86. In: Y.P.S. Bajaj (ed.). Biotechnology in agriculture and forestry. Trees I. vol. I. SpringerVerlag, Berlin.

Shulman, Y., L. Fain Berstein, and S. Lavee. 1984. Pomegranate fruit development and maturation. J. Hort. Sci. 59 (2): 265-274.

Smýkalová, I., P. Smirous, Jr., M. Kubosiová, N. Gasmanová, and M. Griga. 2009. Double haploid production via anther culture in annual, winter type of caraway (Carum carvi L.). Acta Physiol. Plant. 31 (1): 21-31.

Steel, R. G. D., and J. H. Torrie. 1980. Principles and Procedures of Statistics. Second Ed. McGraw-Hill Book Company Inc., New York.

Stiles, H. D., Biggs, R. H., Sherman W. B. 1980. Some factors affectıng callus production by peach anthers. Proc. Fla. State Hort. Soc. 93: 106-108.

Todorovic, R. R., P. D. Mišic, D. M. Petrovic, and M. A. Mirkovic. 1990. Anther culture of peach cultıvars 'cresthaven' and' vesna'. In Vitro Culture, XXIII IHC 300, 331-334.

Wetzstein, H. Y., N. Ravid, E. Wilkins, and A. P. Martinelli. 2011. A morphological and histological characterization of bisexual and male flower types in pomegranate. J. Amer. Soc. Hort. Sci. 136 (2): 83-92.

Yurtsever, N. 1984. Deneysel Istatistik Metotları. Köy Hizmetleri Toprak ve Gübre Arş. Enst. Müdürlüğü Yavınları Genel Yayın No. 121 Ankara.

Zhang, Y. X., Y. Lespinasse, and E. Chevreau. 1989. Induction of haploidy in fruit trees. In: I International Symposium on In Vitro Culture and Horticultural Breeding. ISHS Acta Horticulturae 280: 293-306. Doi: 10.17660/ActaHortic.1990.280.51. 